\title{
Religious Courses in Turkish Public Education: Explaining Domestic Change with Europeanization Theory
}

\author{
Ioannis N. Grigoriadis and Tugba Gurcel
}

Religious education is one of the key indicators determining state attitudes toward religion and is thus inextricably linked to the secularization experience of each state. It is a major asset in evaluating religious freedom because the extent of freedom enjoyed by parents in deciding the education of their children is a good sign of the religious freedom citizens enjoy. In Turkey, the discussion on religious education has revolved around three main issues: (1) the status of religious courses in public education, (2) vocational religious education, and (3) faculties of divinity. Since the foundation of the Republic of Turkey in 1923, all three fields have been subjected to hot debates and have been associated with a long and protracted Kulturkampf between the secularist and the religious conservative segments of the society. Religious minorities, as well as the adherents of different teachings of Islam, have suffered the most because of the status of religious courses in the public education.

As Turkey's European Union (EU) accession negotiations continue, albeit at a slow pace, state-religion relations still cause fervent debates. Religious education, as one of the indicators of a state's stance toward religion and minority rights, has been subjected to

IOANNIS N. GRIGORIADIS (JD, National \& Kapodistrian University of Athens; MIA, Columbia University; PhD, University of London) is assistant professor of political science at Bilkent University. He is author of Instilling Religion in Greek and Turkish Nationalism: A "Sacred Synthesis" and Trials of Europeanization: Turkish Political Culture and the European Union. His articles have appeared in Democratization, Journal of Balkan and Near Eastern Studies, International Journal, Mediterranean Politics, Middle Eastern Studies, Middle East Journal, Middle East Policy, Southeast European and Black Sea Studies, and World Policy Journal. Special interests include comparative politics, religion, nationalism, and European politics. Tugba Gurcel holds a BA and an MA degree in International Relations from Bilkent University. She is currently a doctoral student at the department of Political Science of the same university.

Journal of Church and State vol. 56 no. 2, pages 300-322; doi:10.1093/jcs/css082 Advance Access publication October 3, 2012

(C) The Author 2012. Published by Oxford University Press on behalf of the J. M. Dawson Institute of Church-State Studies. All rights reserved. For permissions, please e-mail: journals.permissions@oup.com 
Europeanization influence. Conflicts arising from religious education have been brought before the European Court of Human Rights (ECtHR) and thus attracted more attention. The annual progress reports prepared by the European Commission on Turkey have also put emphasis on religious education in Turkey. The main issues that were subjected to criticism from the EU were compulsory religious courses in public education and vocational education of religious minorities. Criticisms mainly derived from the principle of freedom of religion and conscience as well as the right of parents to have their children educated in accordance with their belief.

This study aims to focus on the impact of Europeanization on the state of religious education in public schools. From a broader perspective, it will shed light on how state-religion relations have been influenced along the European integration process. Attitude and policy changes noted especially in the last decade will be evaluated according to the Europeanization theory. In compliance with rationalist institutionalist approaches of Europeanization theory, this study will explore whether and how Turkey started to comply with European norms even in a highly debated field like religious education. It will be argued that the change of state attitude on religious education can be explained by Europeanization theory-and more specifically-with differential empowerment of some actors, a process put forward by rationalist institutionalism.

Turkey has experimented with different practices in terms of religious education, and each and every phase can be associated with the general political environment in the country. The status of religious courses in public education has been altered many times, and different methods have been tried: at times the courses were totally removed from the curriculum; they became optional during the regular school/out-of-school hours; they have been compulsory for many years. Currently, within the new system of education, ${ }^{1}$ they are, in principle, elective, although a "secular" version of religious instruction remained compulsory. The contemporary debates in the country will be explored in order to demonstrate how compulsory religious courses have been contentious and how the state has responded. This study aims to explain the pattern of

1. With the amendment of the law on the new education system, known as " $4+$ $4+4$," religious education has become optional for secondary schools and high schools (in addition to the current compulsory religious culture and ethics course). A course on the Koran and a course on the life of Prophet Mohammad are the two religious courses issued under article 9 of the Law No. 6287 which, was amended on March 30, 2012 and promulgated in the Official Gazette on April 11, 2012. Other optional courses will be determined by the Ministry of Education. For the full version of tLaw No. 6287, visit http://www.resmigazete. gov.tr/eskiler/2012/04/20120411-8.htm. 
change in the conduct of religious courses in public education and analyze how Europeanization affected state's attitude toward religion on the axis of religious freedom. The complaints of nonMuslim minorities and Alevis have constituted the core of the discontents on compulsory religious courses. With the transition to the new system, new clashes seem to be added.

\section{Europeanization and Its Impact}

Europeanization is defined as a process in which domestic structures change in response to further settlement of common policies or institutions at the EU level. No total convergence or divergence of national policies and institutions with European ones is expected; what is anticipated is rather "domestic adaptation with national colors." ${ }^{2}$ In order for domestic change to occur under the impact of Europeanization, "there must be some degree of 'misfit' or incompatibility between European-level processes, policies and institutions, on the one hand, and domestic-level processes, policies and institutions on the other." ${ }^{3}$ This is followed by the view that the "penetration" of European rules, practices, and norms into "the otherwise differentiated domestic spheres" is the main reason of domestic change in the course of integration. ${ }^{4}$ Domestic change occurs if there is a case of "misfit," which means that European and domestic policies, processes, and institutions do not match. ${ }^{5}$ The assumption about the level of misfit and its consequence is that the greater the misfit the greater will be the adaptational pressures. Nonetheless, countries faced with similar pressures for adaptation do not necessarily respond with identical domestic structural change, thus there should be mediating factors that are specific to each country. ${ }^{6}$

The attitudinal change in the Turkish case in terms of religious education in public schools can be evaluated in two domains: The

2. Thomas Risse, Maria Green Cowles and James Caporaso, "Europeanization and Domestic Change: Introduction," in Transforming Europe: Europeanization and Domestic Change, ed. Maria Green Cowles, James Caporaso, and Thomas Risse (Ithaca, NY: Cornell University Press, 2001), 1.

3. Tanja A. Börzel and Thomas Risse, "Conceptualizing the Domestic Impact of Europe," in The Politics of Europeanization, ed. Kevin Featherstone and Claudio Radaelli (Oxford: Oxford University Press, 2003), 58.

4. Peter Mair, "The Europeanization Dimension," Journal of European Public Policy 11, no. 2 (2004): 4.

5. Risse, Cowles, and Caporaso, "Europeanization and Domestic Change: Introduction," 6.

6. Tanja A. Börzel and Thomas Risse, "Conceptualizing the Domestic Impact of Europe," in The Politics of Europeanization, ed. Kevin Featherstone and Claudio Radaelli (Oxford, UK: Oxford University Press, 2003), 59. 
first field that should be analyzed within the scope of attitudinal change is legal structure, within which domestic legislation started to comply more or less with the decisions of the ECtHR. The second is state stance, which can be evaluated within the scope of the steps taken in the last few years, such as textbook and curriculum changes in accordance with the "Alevi opening." These changes have been repeatedly highlighted by the EU annual progress reports and also with the latest reform in the education system, which intends to make religious courses elective. Evaluating the change in state attitude from the scope of Europeanization theory and assessing whether fit-misfit, adaptational pressures, mediating factors, and differential empowerment have worked in the Turkish case, can provide an explanation for this change and contribute to theoretical conclusions.

By making reference to the decision of the ECtHR on the exemption from compulsory religious courses, ${ }^{7}$ one can state that Turkey is a case of "misfit" because its domestic legislation seems to contradict with European norms on human rights in this specific field. The impact of Europeanization on domestic legal structures is again dependent on the principle of "the greater the misfit, the greater the adaptational pressures":

Europeanization of the law places identical demands on national judges. However, the goodness of fit between domestic institutions and European requirements determines the extent to which Europeanization generates pressures for adaptation in national legal structures."

In this case, it can be argued that Turkey has been faced with strong adaptational pressures within its legal structures. This is not astonishing given that "membership Europeanization works to a large extent through legal coercion." ${ }^{9}$ It seems also important to analyze how Turkey responded to those pressures stemming from its high degree of legal misfit. To do that, it would be useful to

7. Hasan and Eylem Zengin v. Turkey, ECtHR, Application no. 1448/04, 9 October 2007. This is the case of an Alevi family who applied to the ECtHR for their daughter to be exempted from religious courses. The case was decided in favor of the applicants. This has been a turning point for Alevi families requesting exemption from religious courses.

8. Lisa Conant, "Europeanization and the Courts: Variable Patterns of Adaptation among National Judiciaries," in Transforming Europe: Europeanization and Domestic Change, ed. Maria Green Cowles, James Caporaso, and Thomas Risse (Ithaca, NY: Cornell University Press, 2001), 100.

9. Tanja A. Börzel and Digdem Soyaltın, "Europeanization in Turkey," Paper presented at the The Transformative Power of Europe conference, Freie Universitat, Berlin, Germany, available at http://www.polsoz.fu-berlin.de/en/v/transformeurope/publications/working_paper/WP_36_Boerzel_Soyaltin_neu.pdf (accessed on 6 September 2012) 
assess "the pressures for domestic adaptation that emanate from the European legal system" as well as the response of domestic legal structures. ${ }^{10}$

The rationalist institutionalist approach expects that "Europeanization leads to redistribution of power among a variety of domestic actors, from legislatures, courts, regional governments, to interest groups and companies." ${ }^{11}$ In the Turkish case, it should be highlighted that the national legislation started to comply with the European one, given the decisions of the Council of State (Yargitay), which were in line with the verdict of the ECtHR about the exemption of Alevi pupils from religious courses. As a general rule, "the presence of conflicts between national and European law generates grievances that motivate legal challenges." 12 In Turkey, however, the national legislation did not challenge the ruling of the ECtHR in the subsequent cases of requests for the exemption from religious courses and even declared that these courses with their existing content should not be compulsory. The case law of the ECtHR has been followed, and this is how the impact of Europeanization can be observed in the field of domestic legislation.

When it comes to criticisms made in EU Commission progress reports and European Commission against Racism and Intolerance (ECRI) reports, Turkey again appears to be a case of misfit and faces strong adaptational pressures. In that sense, the Europeanization theory foresees a domestic change due to a high level of misfit only if there are some factors that enable this change in the country. In this state-level analysis, the mediating factors are identified as "multiple veto points in domestic structure, facilitating formal institutions, a country's organizational and policymaking cultures, the differential empowerment of domestic actors, and learning." 13 Rationalist institutionalism mainly argues that the domestic change is dependent on the interests of domestic actors, who are treated as "rational, goal-oriented and purposeful."14 According to this approach, Europeanization is an "emerging political opportunity" that brings additional powers to some actors but constrains some others. ${ }^{15}$ Therefore, rational actors working for

10. Conant, "Europeanization and the Courts: Variable Patterns of Adaptation among National Judiciaries," 99.

11. Risse, Cowles, and Caporaso, "Europeanization and Domestic Change: Introduction," 11.

12. Conant, "Europeanization and the Courts: Variable Patterns of Adaptation among National Judiciaries," 99.

13. Risse, Cowles, and Caporaso, "Europeanization and Domestic Change: Introduction," 2.

14. Börzel and Risse, "Conceptualizing the Domestic Impact of Europe," 63.

15. Ibid. 
their interests make use of this situation by encouraging the implementation of norms and policies brought up by Europeanization. This approach can explain how facilitating factors were present so that Europeanization could lead to domestic change in Turkey in this specific field.

It should be noted that the current Justice and Development Party (Adalet ve Kalkınma Partisi [AKP]) government in Turkey, which has been in charge since 2002, originated from a Islamist political movement but has departed from its roots in various ways but especially in reference to its view on Turkey's EU membership. ${ }^{16}$ The AKP's resolve for Turkey's EU membership has become a way of proving that it has abandoned the Islamic agenda. Therefore, complying with the norms brought by Europeanization and implementing them can be considered as showing loyalty to their commitment and is thus in the interest of the AKP government in terms of securing its position in the country. As a rational actor, the AKP government has to be aware that EU membership, if it occurs during their term of government, will enhance their power while weakening their unelected opponents.

This study also addresses the position of the major oppositionthe Republican People's Party (Cumhuriyet Halk Partisi [CHP])-in dealing with the complaints of the Alevi community. This will help us evaluate the "differential empowerment" effect of Europeanization. The CHP has been known for its affinity to the Alevi community and support for the abolition of compulsory religious courses. Survey data show that those who are against the compulsory religious courses are more likely to be CHP voters and of Alevi origin. ${ }^{17}$ However, due to the steps recently taken by AKP toward a reconciliation with the Alevi community (Alevi Açlımı [Alevi Opening]), the AKP can be said to have attempted a challenge of the preferential relationship between the Alevis and the CHP. This move, made under the impact of Europeanization, empowered the AKP and even became an emerging political opportunity, as highlighted by a rational institutionalist approach. Change in syllabus, the publication of new textbooks, and the recent amendment made in the education system, which makes religious courses, in principle, elective, are the concrete steps taken by the AKP government in reference to religious courses. Given these domestic changes, it would not be wrong to summarize the situation as:

16. İhsan D. Dağı, "Transformation of Islamic Political Identity in Turkey: Rethinking the West and Westernization," Turkish Studies 6, no. 1 (2005): 24. 17. Ali Çarkoğlu and Binnaz Toprak, Religion, Society and Politics in a Changing Turkey (Istanbul, Turkey: TESEV, 2007), 59. 
... Europeanization only leads to a redistribution of resources and differential empowerment at the domestic level if (1) there is significant misfit providing domestic actors with additional opportunities and constraints ... and (2) domestic actors have the capacities to exploit such new opportunities and avoid constraints, respectively. ${ }^{18}$

The AKP seems to have benefited from this process, especially given the absence of "multiple veto points" in Turkey, which could be considered the main obstacle to domestic adaptation. ${ }^{19}$ Due to three terms of single-party government, relative political stability has prevailed-compared with the previous multi-party coalition government period - that has, to some extent, restrained the presence of veto points. In addition, the power of military and bureaucratic veto holders has all but diminished, and this enabled the AKP "to introduce domestic reforms which are to a large extent in line with its own political agenda." 20 It is thus plausible to assert that the Europeanization process has empowered a group of political actors and resulted in the weakening of multiple veto points.

\section{State of Religion in Public Education in the Republican Era}

With the founding of the Republic of Turkey in 1923, nationbuilding became the top priority, and any diversity in education reflecting different worldviews could not be tolerated. The demographic weight of minorities had already fallen sharply in the transition from the Ottoman Empire to republican Turkey, and the provisions of the 1923 Treaty of Lausanne protecting minority rights were often violated. With the 1924 Law on Unification of Education (Tevhid-i Tedrisat), religious medreses were closed and secular mekteps were declared the only institutions of education. ${ }^{21}$ Mustafa Kemal (Atatürk) ${ }^{22}$ underlined that every individual has to learn one's religion; that is why there is need of an institution where every individual-man and woman-can learn one's religion, and this institution is mektep. ${ }^{23}$ In that sense, religious education was not removed from public education, but it was put under the

18. Börzel and Risse, "Conceptualizing the Domestic Impact of Europe," 64.

19. Ibid.

20. Börzel and Soyaltın, "Europeanization in Turkey," 13.

21. Cahit Baltacı, "Türk Eğitim Sisteminin Tarihi Gelişimi” in Türkiye'de Din Ĕgitimi ve Öğretimi, ed. İslam Medeniyeti Vakfı (İstanbul, Turkey: Güzel Sanatlar Matbaası, 1993), 14.

22. Surnames were introduced in Turkey in 1934.

23. Fahri Unan and Yücel Hacaloğlu, Cumhuriyetin 75. Yllında Türkiye'de Din Eğitimi ve Öğretimi (Ankara, Turkey: Türk Yurdu, 1999), 230. 
firm control of the state and the supervision of the Ministry of National Education. ${ }^{24}$

The reform in public education should be evaluated within the framework of overall secularization of the country. Locating religious instruction within the secular education system was functional in the sense that it could impede the divergence that would come out as a result of different sects and interpretations of Islam. ${ }^{25}$ In order to fully control religion and give an end to the power of tarikat leaders, Mustafa Kemal introduced a new understanding of laicism. Kemalist laicism claimed to be based on rational thinking. In his perception, secularization meant depriving the traditional power of ulema in order to consolidate the understanding of "rational religion." ${ }^{26}$ What was meant by "rational religion" was "to reduce the social significance of religious values and to eventually disestablish cultural and political institutions stamped by Islam." ${ }^{27}$ The main goal was to teach people to refer to positivist thinking in their daily lives rather than to the sayings of ulema. Therefore, reform in the education system was more than an institutional amendment; it also aimed to elevate "citizens of the future" committed to the principle of laicism.

One of the fundamental steps for secularization was taken in the field of education in order to "establish a program of functional differentiation of institutions." 28 The well-known outcome of this move was the Tevhid-i Tedrisat of 1924, which ended the bifurcated nature of education whereby religious-oriented instruction was provided by medreses and secular instruction by mekteps. With this law, all educational institutions became associated to the Ministry of National Education. In this way, religious education was pulled out of the control of religious orders. A Directorate of Religious Affairs (Diyanet İşleri Başkanlığl) was established in 1924 to manage the administrative affairs of religion. ${ }^{29}$ Mustafa Kemal also found it necessary to train religious personnel and made this function an exclusive competence of the state. In order to realize

24. Recep Kaymakcan, “Türkiye'de Din Eğitimi Politikaları Üzerine Düşünceler,” EKEV Akademi Dergisi, 10, no. 27 (2006): 486.

25. Halis Ayhan, Türkiye’de Din Eğitimi (İstanbul, Turkey: Marmara Üniversitesi İlahiyat Fakültesi Vakfı, 1999), 64.

26. Pinar Tank, "Political Islam in Turkey: A State Controlled Secularity," Turkish Studies 6, no. 1 (2005): 6.

27. Ibid.

28. Talip Küçükcan, "State, Islam, and Religious Liberty in Modern Turkey: Reconfiguration of Religion in the Public Sphere," BYU Law Review 2 (2003): 488. 29. Niyazi Berkes, The Development of Secularism in Turkey (Montreal, Canada: McGill University Press, 1964), 484. 
this, imam-hatip schools ${ }^{30}$ (religious vocational high schools) and a faculty of divinity (at Dar-ül-Fünun, later Istanbul University) were established in $1924 .{ }^{31}$ To summarize the position of religious education within the general education system in those years, religious education in its new form mainly aimed at eliminating the influence of nonstate religious actors and enhancing the formation of individual belief through the establishment of separate schools to train religious personnel. ${ }^{32}$

The state of religion in public education during the single-party period in Turkey ${ }^{33}$ needs to be evaluated from different angles. During the first couple of years of the new republic, enthusiasm about the ideal model put forward by Mustafa Kemal, in which religious education was subjugated to the secular education system, was dominant. The new state elite were immersed in the implementation of reforms in light of modernization and secularization. ${ }^{34}$ Article 2 of the constitution, which made Islam the state religion, was amended, and from thereon, there has been no official state religion in Turkey. At that time, religious freedom was no concern; on the contrary, the state was exerting strict control over religion in public life. From the early 1930s onward, the country faced religious-oriented rebellions, which could be interpreted as evidence that laicism had not been, in principle, accepted. Its insertion in the constitution did not necessarily mean that laicism had been embraced by all parts of society. ${ }^{35}$ These rebellions raised concerns that religion still posed a threat to the principles set for the new republic.

Religious education was inevitably affected by this atmosphere and faced several restrictions. All these developments ended with the closure of imam-hatip schools, the end of faculties of divinity, and the gradual removal of religious courses from the public education at the beginning of the 1930s. The existence of religious education in public schools and the presence of imam-hatip schools were perceived as tools for the continuation or take-over of the old

30. The law on unification of education also determined the foundation of new schools to train religious personnel. Therefore, imam-hatip schools were founded with this name in the year of 1924 .

31. Berkes, The Development of Secularism in Turkey, 484.

32. Unan and Hacaloğlu, Cumhuriyetin 75. Yılında Türkiye'de Din Eğitimi ve Öğretimi, 250-51.

33. This indicates the period between the foundation of the republic and transition to multi-party politics from 1923 to 1946.

34. Faroz Ahmad, Modern Türkiye'nin Oluşumu (İstanbul, Turkey: Kaynak Yayınları, 1995), 71.

35. İștar Gözaydın, Diyanet: Türkiye Cumhuriyeti'nde Dinin Tanzimi (İstanbul, Turkey: İletişim, 2009), 26. 
shari'a-driven mentality of governing the state and society. ${ }^{36}$ To prevent the damage that could be given by the old thinking, the single-party rule abolished all institutions giving religious education and removed religious courses from the school curriculum. The single-party CHP government was keen on shaping each and every institution of the state in accordance with its religious ideology. ${ }^{37}$

In 1946, with the establishment of the Democrat Party (Demokrat Parti [DP]), people started expressing their views more openly, benefiting from the relatively more liberal environment. The enhancement of the role of religion in their daily life constituted a major issue. $^{38}$ In line with democratization steps that were taken, the need of society to practice its beliefs more liberally and assertively did not escape the attention of political parties on the scene. Therefore, it was neither the requisites of religion nor solely the need of Turkish people to live their religion but it was mainly the will of political parties, which wanted to make use of this inclination. ${ }^{39}$ The need of Turkish people for reinsertion of religion into daily life was so obvious that even the CHP, the party founded by Atatürk and strongly attached to the principle of laicism, had to restore its discourse on religion and laicism and follow a more flexible policy. 40

In that respect, religious education became a critical issue to be emphasized and discussed in the parliament. ${ }^{41}$ With a decision of the parliament in 1948, religious courses were reintroduced in the primary schools in fourth and fifth grades as elective courses outside of ordinary school hours. ${ }^{42}$ When the discussions in the parliament are evaluated, the reasons for including religious courses in the curriculum appear diverse, but they mostly stem from social concerns. Among the main reasons for a positive attitude toward religious courses, one could count teaching students to respect elderly people and utilizing the impact of religion against the threat of communism. ${ }^{43}$ The foundation of a new faculty of divinity at Ankara University in 1949 can also be assessed

36. See Unan and Hacaloğlu, Cumhuriyetin 75. Yılında Türkiye'de Din Eğitimi ve Öğretimi, $272-73$.

37. Baltacl, "Türk Eğitim Sisteminin Tarihi Gelişimi," 14.

38. Ahmad, Modern Türkiye'nin Oluşumu, 132.

39. Gözaydın, Diyanet: Türkiye Cumhuriyeti’nde Dinin Tanzimi, 28.

40. Ibid.

41. Baltacı, "Türk Eğitim Sisteminin Tarihi Gelişimi," 16.

42. Ayhan, Türkiye'de Din Eğitimi, 118.

43. Gözaydın, Diyanet: Türkiye Cumhuriyeti’nde Dinin Tanzimi, 29; Kaymakcan, "Türkiye'de Din Eğitimi Politikaları Üzerine Düşünceler", 23; Ayhan, Türkiye'de Din Eğitimi, 113. 
as the result of the policy followed by the CHP on increased flexibility in the interpretation of laicism in favor of religion. ${ }^{44}$

With the DP's rise to power in 1950, the role of religion in social engineering became evidently concessive in comparison with the previous period. ${ }^{45}$ The DP administration prioritized the role of religion in public life. This was first reflected by developments in religious education; beginning in 1950, religious courses entered the curriculum of primary schools-but they were still elective. ${ }^{46}$ In 1951, imam-hatip schools were opened. ${ }^{47}$ In 1956, religious courses were added to the curriculum for both primary and secondary schools (ilkokul-ortaokul). The insertion of elective religious courses to the curriculum of high schools (lise) took place in 1967 under the rule of the Justice Party (Adalet Partisi [AP]), which was another political party that took into account the religious sensitivities of Turkish people. ${ }^{48}$ Religious education spread at almost every level-primary, secondary, and high schools-and the number of imam-hatip schools grew gradually. In the following years, the governments enhanced religious education. In line with that, the need for courses on ethics (ahlak) was considered, so that in 1974 courses on ethics became compulsory at secondary and high schools. ${ }^{49}$ To summarize the situation in terms of religious education: the number of imam-hatip schools increased as did the number of Higher Islamic Institutes (Yüksek Íslam Enstitüsü), ${ }^{50}$ and there were elective religious and compulsory ethics courses in the public education. This was the state of affairs right before the military coup of September 12, 1980.

The major idea brought up by the 1980 military coup, which had great impact on the conduction of religious education in Turkey, was that the polarization in the country in terms of the clash between rightist and leftist ideologies among youth was derived from the lack of knowledge about religion. To put it in another

44. Kaymakcan, “Türkiye'de Din Eğitimi Politikaları Üzerine Düşünceler,” 23.

45. Gözaydın, Diyanet: Türkiye Cumhuriyeti'nde Dinin Tanzimi, 32.

46. Ayhan, Türkiye'de Din Eğitimi, 125; Gözaydın, Diyanet: Türkiye Cumhuriyeti'nde Dinin Tanzimi, 33.

47. Mehmet Ali Gökaçtı, Türkiye'de Din Eğitimi ve İmam Hatipler (İstanbul: İletişim Yayınları, 2005), 189.

48. Ayhan, Türkiye'de Din Eğitimi, 132.

49. Kaymakcan, “Türkiye'de Din Eğitimi Politikaları Üzerine Düşünceler,” 23.

50. The first was founded in 1959 in Istanbul. When religious courses entered public education curricula, there emerged a need for teachers to instruct these courses. The number of the graduates of the faculty of divinity was insufficient. Because of the status of imam-hatip schools, their graduates were not eligible to continue their education in faculties of divinity. For this reason, the number of Higher Islamic Institutes in Turkey reached nine by the end of the 1970s. See Berkes, The Development of Secularism in Turkey. 
way, lack of appropriate understanding of Islam allowed young people to be influenced by multifarious ideologies. General Kenan Evren, who led the coup, underlined that if Turkish youth had known Islam properly, they would have not be influenced by Marxism. The 1980 coup leadership was aware that religion is both a system of ethics and glue for solidarity, so they perceived religion as the antidote to social and political polarization. ${ }^{51}$ The underpinnings of this thinking lie in an ideology that has been developed by intellectuals since the 1960s. The "Turkish-Islamic Synthesis" was put forward by Hearth of the Enlightened (Aydınlar Ocă̆ı), which was founded as a discussion club without political ambitions. ${ }^{52}$ At first, this concept appeared to be an attempt to integrate nationalists and Islamists on the grounds of revitalizing the "essence" of Turkish culture. The propositions they offered in seminars they organized and through other platforms constituted the basis of the policies followed in the post-1980 period. One of their theses was that the polarization in the country in the 1960s and 1970s was due to wrong educational policies followed by strictly secular republican governments who admired Western culture. For the Turkish-Islamic Synthesis to be implemented, the Western secularist impact on education, which gave students a materialistic worldview, had to be put away. ${ }^{53}$

In line with this thinking, the military regime decided to unify the courses of ethics and religion under one course called "religious culture and knowledge of ethics" and make it compulsory. ${ }^{54}$ This arrangement defining the status of religious courses at primary and secondary schools was inserted into the constitution of 1982, which was prepared under the military regime. Article 24 of the 1982 constitution made teaching of religious culture and knowledge of ethics courses mandatory in primary and secondary schools. Thus, the constitution of 1982 differed from the previous one (the constitution of 1961) in discussing religious education in the related article of "freedom of religion and conscience." 55 There was also an advantageous step taken for the imam-hatip schools; with the amendment of the law on education, the graduates

51. Metin Heper, Türkiye Sözlüğü: Siyaset, Toplum ve Kültür (İstanbul, Turkey: Doğu-Batı Yayınları, 2006), 349.

52. Binnaz Toprak, "Religion as State Ideology in a Secular Setting: The TurkishIslamic Synthesis" in Aspects of Religion in Secular Turkey, ed. Malcolm Wagstaff (Durham, UK: Centre for Middle Eastern and Islamic Studies, University of Durham, 1990), 10.

53. Ibid.

54. Ayhan, Türkiye'de Din Eğitimi, 246.

55. Gözaydın, Diyanet: Türkiye Cumhuriyeti’nde Dinin Tanzimi, 46. 
of these schools were allowed to continue their studies in any field for university education.

In the 1990s, there was no significant change in the status of religious courses in public education despite the tension between the government $^{56}$ and military that peaked in 1997, which is known as the "28 February process" or "post-modern coup" or "soft coup." The major outcome of this process for the education system was the eight-year compulsory primary education law ${ }^{57}$; as a result of the decision of the Ministry of Education, the secondary education branch (orta kısim) of imam-hatip schools was closed down, and the role of imam-hatip schools was reduced to training religious personnel. ${ }^{58}$ In addition, it became more difficult for the graduates of imam-hatip schools to continue their studies in the field of their preference. ${ }^{59}$ As an extension, a secularist emphasis was added to the curricula of all primary and secondary schools. ${ }^{60}$ On the other hand, the soft coup did not bring about any change in the position of religious courses; these remained obligatory both in primary and secondary education.

\section{The Current State of Affairs: Reform, Alevis, and Beyond}

It should be noted that the current status of state-religion relations in Turkey has been one of the main sources of controversy regarding the country's membership of the EU. Fervent debates about Turkey's potential EU integration were not only based on its religion or cultural "otherness" within a wider context of a Huntingtonian "clash of civilizations," ${ }^{61}$ but they also focused on the role of religion in European identity and Islam in European society. On the

56. There was a coalition government at that time, which was formed by a center-right party, the True Path Party (Doğru Yol Partisi), and the Islamist Welfare Party (Refah Partisi). The military was concerned about the government's commitment to laicism.

57. The Law for Eight-Year Compulsory and Uninterrupted Education no. 4306: "The primary education institutions shall comprise of eight-year schools, non-stop education shall be provided by these schools and primary education diplomas shall be given to graduates of such schools." Available online at: http://www.meb.gov.tr/Stats/apk2001ing/Section_4/CompulsoryEducation1.htm.

58. İrfan Bozan, Devlet ile Toplum Arasinda (İstanbul: TESEV, 2007), 20.

59. Gökaçtı, Türkiye’de Din Eğitimi ve İmam Hatipler, 246.

60. Ümit Cizre and Menderes Çınar, "Turkey 2002: Kemalism, Islamism, and Politics in the Light of the February 28 Process," South Atlantic Quarterly 102, nos. 2/3 (2003): 312.

61. Samuel P. Huntington, The Clash of Civilizations and the Remaking of World Order (New York: Simon \& Schuster, 1996). 
one hand, many Europeans objected to Turkey's EU membership, stating that it was culturally incompatible with Europe due to its Islamic identity and could put the European integration project into danger. ${ }^{62}$ In their view, the Ottoman Empire comprised for centuries the quintessential European "other," and republican Turkey did not share the Judeo-Christian cultural roots of Western European civilization, which are considered indispensable for building a common European identity. The integration problems that Muslim immigrants have faced and the alleged failure of multiculturalism in several Western European states have been presented as additional evidence for the futility of Turkey's EU integration project.

On the other hand, other Europeans who favored secular definitions of European identity argued that Turkey's Islamic identity should not be seen as an obstacle but indeed an asset in the country's membership accession process. In their view, secularism has been one of the key legacies of the Enlightenment, and the European project has been established on secular liberal democratic values. Turkey's application, should, therefore, be judged on the country's adoption of these values and not on the basis of its religion. The membership of a country such as Turkey would manifest that the EU is indeed a secular organization that could make a major contribution to intercultural dialogue and help bridge the gap between the West and the Islamic world. In light of this, EU criticisms have revolved around domestic legislation about religious freedom. Such issues, which have been highlighted in annual progress reports and often become a matter of discussion in the country, have involved the protection of the rights of religious minorities, compulsory religious courses, the function of the Directorate of Religious Affairs, and the excessive role of the military as the guardian of secularism in the country. ${ }^{63}$

Meanwhile, divergent views on state-religion relations have also been reflected in Turkey's domestic debate regarding EU membership. European liberal and secular attitudes on the question of religious freedom and state control of religion have attracted support from liberal and conservative circles in Turkey, which considered the EU a crucial ally in mitigating Kemalist laicism. On the other hand, supporters of laicism have viewed European pressure to allow for a greater role of Islam in the public sphere with suspicion. ${ }^{64}$ Islamophobic views of Turkey and its EU membership

62. Jose Casanova, "Religion, European Secular Identities, and European Integration," in Religion in an Expanding Europe, ed. Timothy A. Brynes and Peter J. Katzenstein (Cambridge, MA: Cambridge University Press, 2006), 78.

63. Ioannis N. Grigoriadis, Trials of Europeanization: Turkish Political Culture and the European Union (New York \& London: Palgrave Macmillan, 2008), 108. 
perspectives have also been mirrored by Islamist Eurosceptic political actors in Turkey who have argued that the EU and Turkey are essentially different and simply incompatible. As in the European debate, these arguments manifest a variety of views about the role of religion in Turkish national identity as well as different approaches on the conduct of religious education in Turkey.

Since the Islamist-rooted AKP came into power in 2002, hot public debates have focused on imam-hatip schools and compulsory religious courses in public education. Controversies about compulsory religious courses in the public education can give better insight regarding Turkey's stance toward religious freedom. As a matter of fact, respect for religious freedom is not only a universal norm but also a principle protected under international agreements of which Turkey is a part. ${ }^{65}$ The right of parents to choose the education their children will receive is another principle that is protected under international human rights treaties. ${ }^{66}$ There are also related clauses in domestic legislation, ${ }^{67}$ as well as an article that arranges the status of religious courses. ${ }^{68}$ Another domestic legal arrangement ${ }^{69}$ has determined the right of non-Muslim minorities (Greeks,

64. Marcie J. Patton, "AKP Reform Fatigue in Turkey: What Has Happened to the EU Process?” Meditarranean Politics 12, no. 3 (2007): 341.

65. Universal Declaration on Human Rights, article 18: "Everyone has the right to freedom of thought, conscience and religion; this right includes freedom to change his religion or belief, and freedom, either alone or in community with others and in public or private, to manifest his religion or belief in teaching, practice, worship and observance." Article 26: "Parents have a prior right to choose the kind of education that shall be given to their children."

66. European Convention on Human Rights, protocol 1, article 2: "No person shall be denied the right to education. In the exercise of any functions which it assumes in relation to education and to teaching, the state shall respect the right of parents to ensure such education and teaching in conformity with their own religions and philosophical convictions."

67. Basic Law of National Education No. 1739, article 12; of date June 16, 1983, and No. 2842: "Secularism shall be the basis of Turkish national education. Religious culture and ethics shall be among the compulsory subjects taught in primary and upper secondary schools, and in schools of these levels."

68. 1982 Turkish constitution, article 24: "Education and instruction in religion and ethics shall be conducted under state supervision and control. Instruction in religious culture and moral education shall be compulsory in the curricula of primary and secondary schools. Other religious education and instruction shall be subject to the individual's own desire, and in the case of minors, to the request of their legal representatives."

69. Decision of the Supreme Council for Education of July 9, 1990: "Following the proposal by the Ministry of Education, pupils of Turkish nationality who belong to the Christian or Jewish religions and who attend primary and secondary schools, with the exception of schools for minorities, are not obliged to follow the classes in religious culture and ethics, provided they affirm their adherence to those religions. If, however, such pupils wish to attend such classes, they must submit a written request from their legal representative." 
Jews, and Armenians) to be exempted from compulsory religious courses, while the complaints of the Alevi community unaddressed.

As delineated above, the status of religious courses in public education has been altered many times since the foundation of the republic. Almost all options were practiced, varying from not including religious courses at all in the curriculum, to making them elective within the curriculum, to making them elective outside of the curriculum, to making them mandatory. Probably, the most controversial reform has been the one that was introduced by the constitution of 1982 under article 24, which made religious culture and knowledge of ethics courses compulsory. The last decade witnessed the most fervent debates, and the state needed to provide explanations for making these courses compulsory in formal education. In order to substantiate the fact that the existence of compulsory religious courses in the curriculum does not contradict but rather enhances the laic character of the state, the Constitutional Court (Anayasa Mahkemesi) issued a verdict in 1998 indicating that the reason for making obligatory such courses is to provide religious education under state control. State supervision is considered the guarantee of impartiality in teaching of religion; in other words, under the control of the state, impartial information on religions was going to be provided so as to impede a misconduct of freedom of education. The Constitutional Court underlined that the name of the compulsory course is not "religious education" but rather "religious culture" and that this nuance makes the aim of these courses clear-to provide impartial information about religions and make the rules of morality embraced. ${ }^{70}$ Nonetheless, this statement that has been put forward to legitimize the compulsory nature of the religious courses has been challenged on the basis of the content of the courses. Because religious minorities were exempted from mandatory religious courses, debates were more frequently directed toward the Alevi community, which is the second largest Muslim religious community in Turkey after Sunnis. The confrontations stemming from discrimination claims of Alevis regarding religious course practices were mainly based on the compulsory nature of courses of religious culture and knowledge of ethics and were included in annual progress reports of the European Commission. Because Alevism is not considered a religion but a sect of Islam, Alevis do not enjoy the rights that non-Muslim minorities have. This constituted the crux of the issue. Alevis are

70. Decision of the Constitutional Court of date September 16, 1998 and of number 52. Full text of the decision is available online at: http://www. anayasa.gov.tr/index.php?l=manage_karar\&ref=show\&action=karar\&id=1420\& content $=$. 
not exempted from compulsory religious courses, despite the fact that the practices and rituals of Sunnis and Alevis differ to a great extent. Therefore Alevis complain about the mandatory religious courses on the grounds that this is a breach of their parental right of choosing the education their children will have in accordance to their beliefs, which is protected under article 2 of protocol 1 of European Convention on Human Rights. ${ }^{71}$

The debate, in a more general sense, has been on the axis of the stance of the secular state toward all convictions, denominations, and sects in its conduct of religious affairs. This is mainly the state's commitment to the protection of religious freedom of all citizens regardless of their conviction and their respect of the rights of parents to have their children educated according to their beliefs. The Turkish state is widely challenged for imposing a Sunni Hanefi interpretation of Islam and thus discriminating against adherents of other convictions. This has been highlighted several times in the progress reports on Turkey prepared by the European Commission. There have been repeated references to the complaints of Alevis and the violation of the rights stemming from international agreements. The reports also put emphasis on the situation of non-Muslim minorities despite their right to be exempted from religious courses, because they have to declare their conviction due to the decision of the Supreme Council for Education of July 9, 1990. It is highlighted that non-Muslim pupils face discrimination because no alternative courses are provided and they attract the attention of teachers and other students. That is why exemption from religious courses did not seem to be a fair solution for Alevi pupils either.

Despite the EU documents that tend to treat the Alevi community $^{72}$ as a religious minority, Alevis do not seem to claim such a

71. Olgun Akbulut and Zeynep Oya Usal, "Parental Religious Rights vs. Compulsory Religious Education in Turkey," International Journal on Minority and Group Rights 15 (2008): 434.

72. The Alevi population in Turkey constitutes approximately 15 percent of the total population. Even if no exact number could be given for the Alevi population in Turkey, it is estimated that the percentage varies from 10 to 20 percent. See Ali Çarkoğlu and Nazlı Çağın Bilgili, "A Precarious Relationship: The Alevi Minority, the Turkish State and the EU," South European Society and Politics 16, no. 2 (2011): 353. Although there are several Alevi associations representing the Alevi identity, it is difficult to talk about a consensus among those associations on the complaints and proposals for resolutions to those problems. In that sense, it is hard to state that the Alevis are organizationally or politically united. See Elisabeth Özdalga, "The Alevis-a 'New' Religious Minority? Identity Politics in Turkey and Its Relation to the EU Integration Process," in Religion, Politics and Turkey's EU Accession, ed. Dietrich Jung and Catharina Raudvere (New York: Palgrave Macmillan, 2008), 187. 
status from the Turkish state; rather, they are seeking recognition. ${ }^{73}$ The Alevis have offered three propositions in reponse to the compulsory religious courses. First, they demanded exemption from mandatory religious courses for Alevi students. Second, they offered a more reconciliatory proposition, suggesting that if the religious courses were to continue to be compulsory because of the constitutional provisions, then the content should be modified in order to include unbiased and accurate information on Alevism. The state was expected to pay much more attention to their content and give proper and adequate information about all religions as well as sects of Islam in order to enhance their equal stance. The last proposition was the total abolition of religious courses on the basis that the state should not provide religious education in its schools, and any kind of religious education should be provided by religious institutions and nongovernmental organizations. ${ }^{74}$

Alevi families have adhered to legal ways to prevent their children from attending compulsory religious culture and knowledge of ethics courses, which they considered to give one-sided information about Islam and neglect Alevism. The prominent case that set a precedent both for the cases that are brought before the ECtHR and to the domestic jurisdiction is the Zengin vs. Turkey ${ }^{75}$ case, which was decided in favor of the applicants, an Alevi family who wanted their daughter to be exempted from compulsory religious courses. This was the first case where the violation of the religious freedom of Alevis was confirmed by international jurisprudence. The decision of the court was based on the content of the course, which was expected to be impartial. It has been underlined that religious culture and knowledge of ethics courses with the current content should not be compulsory. The court concluded that "the instruction provided in the school subject 'religious culture and ethics' cannot be considered to meet the criteria of objectivity and pluralism."76 In view of this, the court unanimously decided that there was a violation of article 2 of protocol No. 1 of the European Convention of Human Rights.

The verdict of the ECtHR became a landmark for Alevi families seeking to have their children exempted from compulsory religious courses. Since then, cases that have been brought before the Yargltay have been decided in favor of the applicants. Despite the compliance of domestic jurisdiction with international jurisdiction, there

73. Özdalga, "The Alevis-A 'New' Religious Minority? Identity Politics in Turkey and Its Relation to the EU Integration Process," 194.

74. Alevi Çalıştayları, Nihai Raporu (Ankara, Turkey: T.C. Devlet Bakanlığı, 2010), 140.

75. Hasan and Eylem Zengin v. Turkey.

76. Ibid. 
have been many problems in the implementation of these exemptions. In the European Commission progress report of 2011, it was indicated that religious courses were still compulsory and that the decision of the ECtHR had not been implemented yet. ${ }^{77}$ The content, the process of exemptions, even though they could be obtained at the national level, and problems that have risen from the very nature of the system have been indicated. In addition to the progress reports, the reports prepared by the European Commission against Racism and Intolerance stated that the initiatives of the Turkish state were not substantial. Even though the European Commission and European Commission against Racism and Intolerance reports gave impulse to Turkey for further reforms, the steps taken by the Turkish state in compliance with the criticisms and suggestions of these reports should not be denied.

When the criticisms made in these reports are evaluated, it can be stated that Turkey has responded approximately on the axis of the demands from the EU side. A change in the syllabus of the religious culture and knowledge of ethics course to include information about Alevism became effective from the 2007-2008 academic year. However, this change was not considered to be sufficient by the EU, and the Alevi community did not find this initiative sincere because no one solicited their involvement in the process. Under pressure from the progress reports, the "Alevi opening" and the following "Alevi workshops" were useful steps. These developments show that the pressures of the decision of the ECtHR and the progress reports of the commission have had a remarkable impact on putting this issue on Turkey's political agenda. ${ }^{78}$ Furthermore, a concrete step taken by the Turkish state was the preparation of new textbooks including information about Alevism. ${ }^{79}$ These textbooks were to be used as of the 2011-2012 school year. $^{80}$ This has been a major result of Alevi workshops and the environment of reconciliation between the state and the Alevi community and a remarkable move for intensifying the principle of religious freedom in the country. In that sense, Turkey's misfit, which is highlighted by the reports prepared by the EU, and membership

77. Commission of the European Communities, 2011 Regular Report on Turkey's Progress towards Accession (Brussels: European Commission, 2011), 29.

78. Ali Tekin, "Modernist Responses to Post-Modern Demands? 'Differential Treatment' in Europeanising Turkey," in Diversity in Europe, ed. Gideon Calder and Emanuela Ceva (New York: Routledge, 2011), 107.

79. NTVMSNBC, Alevilik Ders Kitaplarına Girdi, September 8, 2011, http://www. ntvmsnbc.com/id/25248445/.

80. Commission of the European Communities, 2011 Regular Report on Turkey's Progress towards Accession, 29. 
conditionality imposed on the country seem to have had a clear impact on domestic policy on the matter of religious education.

\section{Conclusion}

In the field of religious education, Turkey has undergone the process of Europeanization in two domains. For one, the national jurisprudence has complied with the European model in the field of religious education. The EU member states as well as the candidate countries that are "subject to policies and institutions diffused by the case law" were influenced by the legal coercion of Europeanization. For Turkey, this can be best observed in the cases that followed the decision of the ECtHR for an Alevi family who wanted their child to be exempted from the religious courses. The fact that in subsequent cases the national courts have decided in favor of the applicants displays the impact of Europeanization in the domestic jurisprudence.

The second domain where the impact of Europeanization is analyzed is the state level, where attitudinal change in the conduct of religious education is investigated. As already mentioned, Europeanization theory foresees that domestic change can occur when there is a case of misfit. Given the compulsory nature of religious education for many years, Turkey has been considered as such. Due to not only the mandatory character of religious education but also the way it was conducted, the content, and the difficulty of getting exemption, Turkey encountered pressures from the EU. The AKP government has taken steps toward responding to those criticisms; it changed the textbooks to include information about Alevism, modified-even though to a small extent-the content of religious courses, and listened to the views of Alevis while making those alterations. While doing so, the AKP government acted in accordance with what rationalist institutionalism puts forward; it used Europeanization as an emerging political opportunity that provided additional resources to exert influence on veto points in the country, such as opposition parties and military. ${ }^{81}$

At the beginning of 2012, if one were asked to comment on the forthcoming policies on religious education in Turkey, one would state that more room for religious freedom could be expected with the preparation of the new constitution and an amendment of the article about compulsory religious education. These expectations would have been explained by the transformative power of Europeanization, with the AKP benefitting from the differential empowerment and thus able to make changes. However, the

81. Börzel and Soyaltın, "Europeanization in Turkey," 8. 
amendment of the education system ("four years + four years + four years model"), which has been declared and widely discussed since mid-February 2012, and ensuing developments have opened up a new field of discussion. With this new education system, religious courses become elective, but a secular version of religious culture and knowledge of ethics course remained compulsory. It is important to note that there are two elective religious courses determined by the law amending the religious education systemone Koran course and one course on the life of Prophet Muhammad. Other elective courses will be determined later by a commission under the Ministry of National Education. This has caused heated debates because it is not yet obvious whether or not religious courses for convictions other than Islam will be provided by the state. The Minister of National Education stated that such courses shall be offered for both Alevis and religious minorities, but the arrangement is not clear for the time being. ${ }^{82}$ The AKP government evaluated this reform as part of the democratization process, adding that it would provide parents and pupils more freedom of choice, including religious education. This is in line with the Europeanization prospect of the country, given that the status of religious courses, which has been repeatedly criticized in annual progress reports, has been subject to alteration. Nonetheless, while the availability of elective courses for other convictions remains ambiguous, the secularist opposition question whether this reform could lead to the opening of the secondary education branch (orta klsim) of imam-hatip, a key item in the agenda of the AKP.

This last point is explained by Europeanization theory, specifically by rationalist institutionalism, as policy makers introduced domestic reforms that complied with the EU demands but were mainly driven by their political agenda. This means that the AKP utilized Europeanization as a tool to legitimize its political agenda, which caused "shallow Europeanization" in the country. It is remarkable that when the Minister of National Education explained the reason for the need of such a reform in the education system, he made reference to the education system in the EU countries. ${ }^{83}$ This reference to European practice could be understood as a legitimization effort. In that sense, the sincerity of the political actors who are empowered by the Europeanization device would be assessed in terms of providing elective courses for the adherents

82. Minister of National Education Ömer Dinçer replied to questions on the new system of education and the arrangement about the religious courses on a TV broadcast. For the full transcript of the interview, see http://www.meb.gov.tr/ haberler/2012/32GunDesifre06042012.pdf.

83. Ibid. 
of convictions other than Sunni Islam and also in terms of the surveillance of whether these are implemented on an egalitarian basis with respect to religious freedom.

Nevertheless, when the whole process in Turkey, since the very beginning of the republican era, is examined, it seems obvious that religious education has always been a matter of political concern. Politicians have acted in accordance with electoral concerns and arranged their policies on religious education in line with political circumstances; that is why they have always been volatile to popular religious sensitivities. In the last decade, during which Europeanization in Turkey has been more effective than ever, many steps were taken in compliance with the EU norms in the conduction of religious courses. Given the enthusiasm for EU membership, the political actors worked hard under the adaptational pressures to overcome the misfits.

The political environment today is different. It can be argued that there is a Europeanization "fatigue," which can be best observed in the evaporation of the AKP administration interest in maintaining the reform momentum that reached a peak between 2002 and $2005 .{ }^{84}$ The slowdown of the reform process, which coincided paradoxically with the start of Turkey's EU accession negotiations, could be explained in terms of the eventual consolidation of the AKP government power against the secularist bureaucracy. Under these circumstances, fast progress in Turkey's EU accession progress was no longer an essential element for the legitimization of the AKP regime. ${ }^{85}$ Public support for Turkey's EU accession fell, and several Turkish officials argued that EU membership was no longer so valuable, that Turkey had alternative projects, and that the EU needed Turkey more than Turkey needed the EU. Mixed signals from the EU side about the expedience of Turkey's EU membership, culminating in the outright opposition of former French President Nicholas Sarkozy, and the European economic crisis also contributed to the disenchantment of Turkish public opinion and government alike. Politics of religious education can comprise a case to decide whether this "fatigue" may be translated into inertia or whether Europeanization is still on the agenda. The elective character of Sunni Islamic religious courses in the new school curriculum complies to a great extent with the expectations of the EU. On the other hand, the willingness of the state to provide

84. The nine reform packages that were passed during this term are known as "harmonization laws," which were mainly aimed at making Turkish legislation compatible with the EU acquis. See Ergun Özbudun, "Democratization Reforms in Turkey, 1993 -2004," Turkish Studies 8, no. 2 (2007): 180.

85. Patton, "AKP Reform Fatigue in Turkey: What Has Happened to the EU Process?,” 355. 
Journal of Church and State

elective courses on other religions or religious cultures devoid of indoctrination would be a good indicator of whether the political actors are keen on sticking to the European norms or whether Turkey is experiencing "shallow Europeanization." 